\title{
Effects of carbonate on the
} electrolytic removal of ammonia and urea from urine with thermally prepared IrO2 electrodes

\section{Journal Article}

Author(s):

Amstutz, Véronique; Katsaounis, Alexandros; Kapalka, Agnieszka; Comninellis, Christos; Uder, Kai M.

Publication date:

2012-09

Permanent link:

https://doi.org/10.3929/ethz-b-000060242

Rights / license:

In Copyright - Non-Commercial Use Permitted

Originally published in:

Journal of Applied Electrochemistry 42(9), https://doi.org/10.1007/s10800-012-0444-y 


\title{
Effects of carbonate on the electrolytic removal of ammonia and urea from urine with thermally prepared $\mathrm{IrO}_{2}$ electrodes
}

\author{
Véronique Amstutz • Alexandros Katsaounis • \\ Agnieszka Kapalka · Christos Comninellis • \\ Kai M. Udert
}

Received: 9 March 2012/Accepted: 30 June 2012/Published online: 4 August 2012

(C) Springer Science+Business Media B.V. 2012

\begin{abstract}
Recent studies have shown that electrolysis can be an efficient process for nitrogen removal from urine. These studies have been conducted with urea solutions or fresh urine, but urine collected in NoMix toilets and urinals has a substantially different composition, because bacteria hydrolyse urea quickly to ammonia and carbonate. In this study, we compared electrochemical removal of nitrogen from synthetic solutions of fresh and stored urine using $\mathrm{IrO}_{2}$ anodes. We could show that in fresh urine both ammonia and urea are efficiently eliminated, mainly through chlorine-mediated oxidation. However, in stored urine the presence of carbonate, arising from urea hydrolysis, leads to an inhibition of ammonia oxidation. We suggest two parallel mechanisms to explain this effect: the competition between chloride and carbonate oxidation at the anode and the competition between chlorate formation, enhanced by the buffering effect of carbonate, and ammonia oxidation for the consumption of active chlorine in the bulk. However, further experiments are needed to support the latter
\end{abstract}

Electronic supplementary material The online version of this article (doi:10.1007/s10800-012-0444-y) contains supplementary material, which is available to authorised users.

V. Amstutz $(\bowtie) \cdot$ A. Kapalka $\cdot$ C. Comninellis Institute of Chemical Sciences and Chemical Engineering, EPFL/SB/ISIC, 1015 Lausanne, Switzerland

e-mail: veronique.amstutz@epfl.ch

A. Katsaounis

Department of Chemical Engineering, University of Patras, 26504 Patras, Greece

\section{K. M. Udert}

Process Engineering, Eawag, Swiss Federal Institute of Aquatic Science and Technology, Überlandstrasse 133, 8600 Dübendorf, Switzerland

e-mail: udert@eawag.ch mechanism. In conclusion, this study highlights the negative consequences of the presence of carbonate in urine solutions, but also in other wastewaters, when subjected to an electrolytic treatment on $\mathrm{IrO}_{2}$ in alkaline media.

Keywords Ammonia electrooxidation . Urea electrooxidation - Inhibition by carbonate . Carbonate electrooxidation · Urine treatment

\section{Introduction}

Ammonia removal is a main objective of municipal wastewater treatment, since free ammonia is a fish toxic and high ammonia loads can cause eutrophication especially in coastal waters [1]. About $80 \%$ of the nitrogen in municipal wastewater originates from urine and recent research has shown that separate treatment of urine is a sensible approach to improve nutrient removal from wastewater [2].

A wide range of processes has been proposed for nitrogen treatment in urine [3]. Some aim to remove nitrogen as gaseous $\mathrm{N}_{2}$, others to recover nitrogen as a fertilizer. Nitrification [4], nitritation/anammox [5] and ammonia stripping [6] are the most extensively tested technologies. Electrolysis is another interesting technology for nitrogen removal from urine. This process could be particularly suitable for small decentralised reactors due to simple process control, high resilience to inflow variations, simple reactor setup and low demand for chemicals [7].

Electrochemical oxidation of ammonia and urea has received considerable attention in the last years, since novel, efficient, and stable electrodes have been developed [8]. Besides ammonia removal from wastewater, electrolysis has also been tested for ammonia sensors [9] and for hydrogen recovery from ammonia and urea $[10,11]$. 
In wastewater treatment the most common mechanism for electrochemical ammonia oxidation is indirect oxidation with chlorine [12]: electrochemically generated hypochlorous acid reacts with ammonia in a mechanism known as breakpoint chlorination [13]. Direct electrochemical oxidation of ammonia has been investigated intensively on platinum, but also on other noble metals and their alloys [14]: at low overpotential, nearly all ammonia is oxidised to $\mathrm{N}_{2}$ following a mechanism that involves the adsorption and dehydrogenation of ammonia $\left(\mathrm{NH}_{3}\right)$ molecules [15]. At higher potentials, electrodes are deactivated by adsorbed nitrogen $\left(\mathrm{N}_{\mathrm{ads}}\right)$, but if the potential is increased above a certain threshold, $\mathrm{Pt}$ is oxidised to $\mathrm{PtO}_{\mathrm{X}}$ and nitrogen oxides such as nitrite and nitrate are formed [14].

Recently, several research groups have presented novel electrodes for direct ammonia oxidation, for example borondoped diamond electrodes (BDD) [16], $\mathrm{Ni} / \mathrm{Ni}(\mathrm{OH})_{2}$ [17] and dimensionally stable anodes (DSA) such as Ti- $\mathrm{IrO}_{2}[18,19]$. Despite preliminary studies on the mechanism of ammonia oxidation on these electrodes [20, 21], the mechanisms are not completely understood. Bunce and Bejan [14] suggested that the mechanism could be considered to be analogous to a metallic Pt or Ir anode that has become covered by an oxide surface. This theory implies that nitrogen oxides can be produced at higher potentials. Kapalka et al. [21] reported another similarity with noble metals electrodes: intermediates of ammonia oxidation are the likely reason for $\mathrm{Ti}-\mathrm{IrO}_{2}$ electrode deactivation at high potentials.

Electrochemical urea degradation has been studied to a much lower extent than ammonia degradation. Simka and Piotrowski [22] tested several DSA electrodes and could show that $\mathrm{N}_{2}$ and $\mathrm{CO}_{2}$ were the main products. In their experiments, urea degradation was mediated by electrochemically formed chlorine. Direct urea degradation was described by Boggs et al. [11] on several noble metals and their alloys. The highest activity, however, exhibited nickel. The low stability of nickel could be improved by electrodepositing rhodium [23].

Few studies have been reported on electrochemical nitrogen removal from urine. Recently, Boggs et al. [11] proposed to use urine as a source of hydrogen, by electrolysing urea with nickel electrodes. They applied the process on a solution containing $1 \mathrm{~mol} \mathrm{~L}^{-1} \mathrm{KOH}$ and human urine. By adding the $\mathrm{KOH}$ solution, a high $\mathrm{pH}$ value was ensured, which is beneficial for the direct oxidation of urea. Whether the system would also work with unchanged human urine, was not tested. Ikematsu et al. [24] tested an electrochemical reactor consisting of an iron electrode positioned between two PtIr electrodes. By changing the direction of the current they could switch between total nitrogen removal and iron dissolution for phosphate precipitation. Most of the experiments were conducted with diluted urine solutions.
To our knowledge, no study on urine electrolysis has considered that the composition of source-separated urine changes considerably in the toilets, pipes and storage tanks. Ubiquitous ureolysing bacteria degrade urea [25]. According to medical literature, fresh urine has an average $\mathrm{pH}$ value of 6.2 , low total ammonia $\left(480 \mathrm{mgN} \mathrm{L}^{-1}\right)$ and $90 \%$ of the nitrogen is bound as urea. After urea hydrolysis, the same urine has an average $\mathrm{pH}$ value of 9.1, more than $90 \%$ of the nitrogen exists as total ammonia $\left(\mathrm{NH}_{3}\right.$ and $\mathrm{NH}_{4}{ }^{+}$) and the total carbonate concentration increased from nearly zero to $3,200 \mathrm{mgC} \mathrm{L}^{-1}$. Concomitantly, the alkalinity of the solution increases as well [26]. All these changes can have a considerable effect on the electrochemical removal of nitrogen, as we will show in this study.

\section{Materials and methods}

Two synthetic solutions featuring human urine immediately after excretion ("fresh urine") and after storage in a urine collection-system ("stored urine") were used. Both solutions were prepared based on the composition given by Udert et al. [26] (details on Table 1 and in supplementary information).

Table 1 shows that the fresh urine solution contained mainly urea as nitrogen species, whereas in the stored urine solution, urea is replaced by ammonia and carbonate. This modification represents the fact that urea is hydrolysed by the enzyme urease produced by microorganisms [25]. As the only organic compound with chemical oxygen demand (COD) (urea does not have a COD), acetate was added to

Table 1 Concentrations of the species initially present in synthetic solutions of fresh and stored urine. The recipes for the solutions are given in Tables 1 and 2 of the supplementary information

\begin{tabular}{lll}
\hline & $\begin{array}{l}\text { Fresh urine } \\
\left(\mathrm{mol} \mathrm{L}^{-1}\right)\end{array}$ & $\begin{array}{l}\text { Stored urine } \\
\left(\mathrm{mol} \mathrm{L}^{-1}\right)\end{array}$ \\
\hline Urea & 0.266 & - \\
Ammonia/ammonium & 0.0337 & 0.568 \\
Chloride & 0.107 & 0.118 \\
Bicarbonate/carbonate & - & 0.271 \\
Acetate & 0.125 & 0.125 \\
Sodium & 0.184 & 0.111 \\
Potassium & 0.0563 & 0.0563 \\
Magnesium & 0.00389 & - \\
Calcium & 0.0046 & - \\
Sulfate & 0.0162 & 0.0162 \\
Phosphate & 0.0242 & 0.0175 \\
Initial pH & 6.1 & 8.8 \\
\hline
\end{tabular}


stored urine. This compound was chosen as representative for the COD compounds, since it makes up about $50 \%$ of the COD in stored urine (own measurements, data not shown). Acetate is formed by fermentation during storage. For the sake of simplicity, we also added acetate as COD source to fresh urine. However, COD was not measured in this experiment since our own experiments showed that is was not degraded at the electrode used (unpublished results).

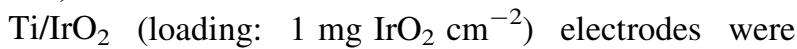
prepared by a thermal decomposition method. More details have been given elsewhere [27].

Electrolysis experiments were carried out at constant temperature $\left(T=25 \pm 1{ }^{\circ} \mathrm{C}\right.$, Polystat cc2, Huber, Germany), under galvanostatic conditions ( $15 \pm 0.3 \mathrm{~mA} \mathrm{~cm}^{-2}$, EA-PS 3065-03B, Conrad, Germany), in a $120 \mathrm{~mL}$ onecompartment cell with two zirconium cathodes and one Ti/ $\mathrm{IrO}_{2}$ anode (geometric surface area: $13.5 \mathrm{~cm}^{2}$ ) in between. Stirring was provided by a magnetic bar and a magnetic stirrer (ARE Heating Magnetic Stirrer, VELP Scientifica, Italy).

$1 \mathrm{~mL}$ aliquots were taken at various time intervals. The solution $\mathrm{pH}$ was measured at every sampling $(\mathrm{pH} 213$ Microprocessor pH-meter, Hanna Instruments, France), and, when necessary, it was adjusted with solutions of $\mathrm{NaOH}$ (Fluka Chemicals, Switzerland) or $\mathrm{HClO}_{4}(60 \%$, ACS, Alfa Aesar, USA). The concentration of both solutions varied between $0.01 \mathrm{mmol} \mathrm{L}^{-1}$ and $1 \mathrm{~mol} \mathrm{~L}^{-1}$ depending on the experiment and the $\mathrm{pH}$ change. The $\mathrm{pH}$ was not adjusted between two consecutive samplings. The cell voltage was recorded at every sampling.

During electrolysis, the active chlorine concentration (sum of $\mathrm{Cl}_{2}, \mathrm{HOCl}, \mathrm{NaOCl}$, and chloramines) was measured by iodometric titration [28], while the total nitrogen (sum of dissolved nitrogen species), total ammonia (sum of free ammonia and ammonium), nitrate and nitrite concentrations were measured photometrically with cuvette tests (Hach Lange GmbH, Germany).

The polarization curves were obtained in a $50 \mathrm{~mL}$ one-compartment cell with three electrodes: the working electrode was a $\mathrm{Ti} / \mathrm{IrO}_{2}$ electrode (geometric surface area: $0.785 \mathrm{~cm}^{2}$ ), the reference electrode was a mercurous sulfate electrode MSE (REF 621, Radiometer Analytical, France) with a potential of $+0.64 \mathrm{~V}$ versus standard hydrogen electrode, and the counter electrode was a platinum wire. These electrodes were connected to the galvanostat-potentiostat ( $\mu$ Autolab Type III, Eco Chemie BV, The Netherlands) and the data were recorded and analysed with the software GPES (Version 4.9.009).

The speciation of carbonate species was calculated with the computer program PHREEQC according to [17]. In the simulations, we used the Pitzer approach to calculate the ion activities.

\section{Results}

\subsection{Electrolysis of synthetic urine solutions}

Figure 1 shows the results of galvanostatic electrolysis $\left(15 \mathrm{~mA} \mathrm{~cm}^{-2}\right)$ of fresh urine (initial $\mathrm{pH}$ 6) and stored urine (initial $\mathrm{pH}$ 9) on $\mathrm{IrO}_{2}$ anode, carried out at $25^{\circ} \mathrm{C}$. The electrical charge passed $Q\left[\mathrm{Ah} \mathrm{L}^{-1}\right]$ was calculated as indicated in the supplementary information section.

During fresh urine electrolysis the $\mathrm{pH}$ value first increased. After passing $Q=45 \mathrm{Ah} \mathrm{L}^{-1}$ it reached a maximum of 7 , and then fell to a value of 5 towards the end of the electrolysis (charge passed $86 \mathrm{Ah} \mathrm{L}^{-1}$ ). During electrolysis of stored urine the $\mathrm{pH}$ remained constant at a value close to 9 .

Figure $1 \mathrm{~A}$ and $\mathrm{C}$ show the measured concentrations of ammonia, nitrate, and total nitrogen species as a function of $Q$ for both fresh urine and stored urine. In the former case, the total nitrogen concentration decreased clearly with time, total ammonia concentration remained low and dropped under the detection limit $\left(2 \mathrm{mgN} \mathrm{L}^{-1}\right)$, and the concentration of nitrate increased, reaching a maximum of $1670 \mathrm{mgN} \mathrm{L}^{-1}$ at the end of the experiment. In the case of stored urine, the concentration of total nitrogen, mainly consisting of ammonia, hardly changed. The total ammonia concentration dropped only slightly during the experiment, partially compensated by the increase of the nitrate concentration. Nitrite concentrations (not shown) remained low: they reached a maximum of $1.6 \mathrm{mgN} \mathrm{L}^{-1}$ for fresh urine, and were below the detection limit $\left(0.6 \mathrm{mgN} \mathrm{L}^{-1}\right)$ for stored urine. Figure $1 \mathrm{~B}$ and $\mathrm{D}$ display the concentration of active chlorine as a function of $Q$ in both solutions. A sharp increase is observed towards the end of the experiment for fresh urine, whereas the level of active chlorine remained very low and quite constant during the entire experiment for stored urine.

\subsection{Effect of carbonate and high $\mathrm{pH}$ value on the electrolysis of fresh urine}

In order to investigate the effects of carbonate on the electrochemical treatment of fresh urine, a first experiment was carried out in presence of $3.24 \mathrm{gC} \mathrm{L}^{-1}$ of carbonate (or $28.6 \mathrm{gNa}_{2} \mathrm{CO}_{3} \mathrm{~L}^{-1}$ ). The resulting $\mathrm{pH}$ value was 10.2 . To separate the effects of carbonate and high $\mathrm{pH}$, a second electrolysis experiment was conducted by adjusting the $\mathrm{pH}$ value to 10.2 by adding $\mathrm{NaOH}$. Figure 2 shows the nitrogen concentrations and the concentration of active chlorine for both experiments. In the experiment with carbonate, the $\mathrm{pH}$ value remained constant without addition of base, while in the experiment without carbonate, the $\mathrm{pH}$ had to be adjusted by adding $\mathrm{NaOH}$ to keep it at a value of 10.2 . Figure 2A shows that urea oxidation was inhibited in the 

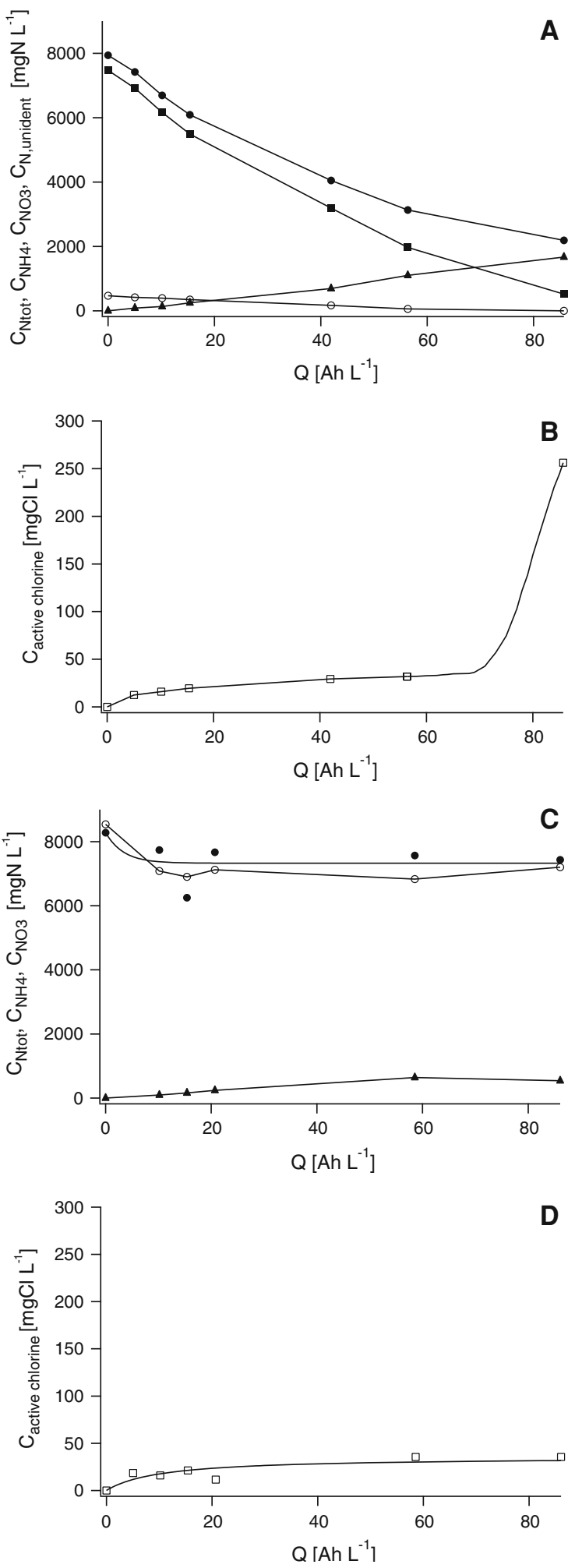

presence of carbonate. The solution without carbonate exhibited a different electrolysis behaviour: the nitrogen measurements depicted in Fig. $2 \mathrm{C}$ show that urea degradation was fast in the beginning of the experiment but essentially stopped when $Q$ passed a value of $10 \mathrm{Ah} \mathrm{L}^{-1}$.
Fig. 1 Galvanostatic electrolysis of synthetic fresh urine, at $\mathrm{pH}$ $6 \pm 1(\mathbf{A}, \mathbf{B})$ and synthetic hydrolysed urine at $\mathrm{pH} 9(\mathbf{C}, \mathbf{D})$. $\mathrm{j}=15 \mathrm{~mA} \mathrm{~cm}{ }^{-2}, \mathrm{~T}=25^{\circ} \mathrm{C}$. Filled circle total nitrogen $\left(\mathrm{C}_{\mathrm{N}_{\mathrm{tot}}}\right)$, open circle ammonium $\left(\mathrm{C}_{\mathrm{NH}_{4}}\right)$, filled triangle nitrate $\left(\mathrm{C}_{\mathrm{NO}_{3}}\right)$, filled square non-identified nitrogen-species $\left(\mathrm{C}_{\mathrm{N} \text {,unident }}\right.$ : at the beginning of the experiment, this must have been urea, but it was not identified by measurements during the experiment), open square active chlorine $\left(\mathrm{C}_{\mathrm{active}}\right.$ chlorine). The formulas for the fitted curves are given in the supplementary information

The initial current efficiency of urea oxidation was high $(86 \%)$. Nitrate was formed during the first part of the experiment. The level of active chlorine was similar in both experiments (Fig. 2B, D).

\subsection{Carbonate study}

In order to understand the effect of high carbonate concentrations on urea and ammonia oxidation, we measured polarization curves in solutions containing $\mathrm{Na}_{2} \mathrm{CO}_{3}$ (various concentrations) and $\mathrm{NaClO}_{4}\left(1 \mathrm{~mol} \mathrm{~L}^{-1}\right)$, firstly as a function of $\mathrm{pH}$ (Fig. 3), and secondly as a function of carbonate concentration (Fig. 4). The curves show that carbonate was oxidised on $\mathrm{IrO}_{2}$ anode at a $\mathrm{pH}$ higher than 9 , with an onset potential of $0.35 \mathrm{~V}$ versus MSE. In both experiments, the height of the current density peak correlated with the concentration of carbonate $\left(\mathrm{CO}_{3}{ }^{2-}\right)$ (inset of Fig. 3 and inset of Fig. 4). The speciation of carbonate was calculated using Pitzer parameters for the carbonate species, that allow incorporating the high ionic strength of the solution into the calculations.

Galvanostatic electrolysis of $0.12 \mathrm{~mol} \mathrm{~L}^{-1} \mathrm{NaCl}$ solutions was carried out in presence and in absence of carbonate $\left(0,1.68,3.24 \mathrm{gC} \mathrm{L}^{-\mathbf{1}}\right)$, for $\mathrm{pH}$ values varying between 6 and 10. The results revealed that carbonate strongly inhibited the formation of active chlorine in the bulk of alkaline solution, but more weakly in neutral and acidic solutions (Fig. 5). Without carbonate, the $\mathrm{pH}$ value had only a small effect on the production of active chlorine.

\section{Discussion}

\subsection{Active chlorine formation}

In all experiments, active chlorine was found in considerably high amounts. Equations 1-3 can describe the formation of active chlorine compounds: chloride was oxidised to chlorine at the $\mathrm{IrO}_{2}$ anode (Eq. 1), and further on chlorine was hydrolysed in the bulk of the solution to form hypochlorous acid and hypochlorite ion (Eqs. 2, 3). These reactions were already observed on $\mathrm{IrO}_{2}$ electrodes [29]. 

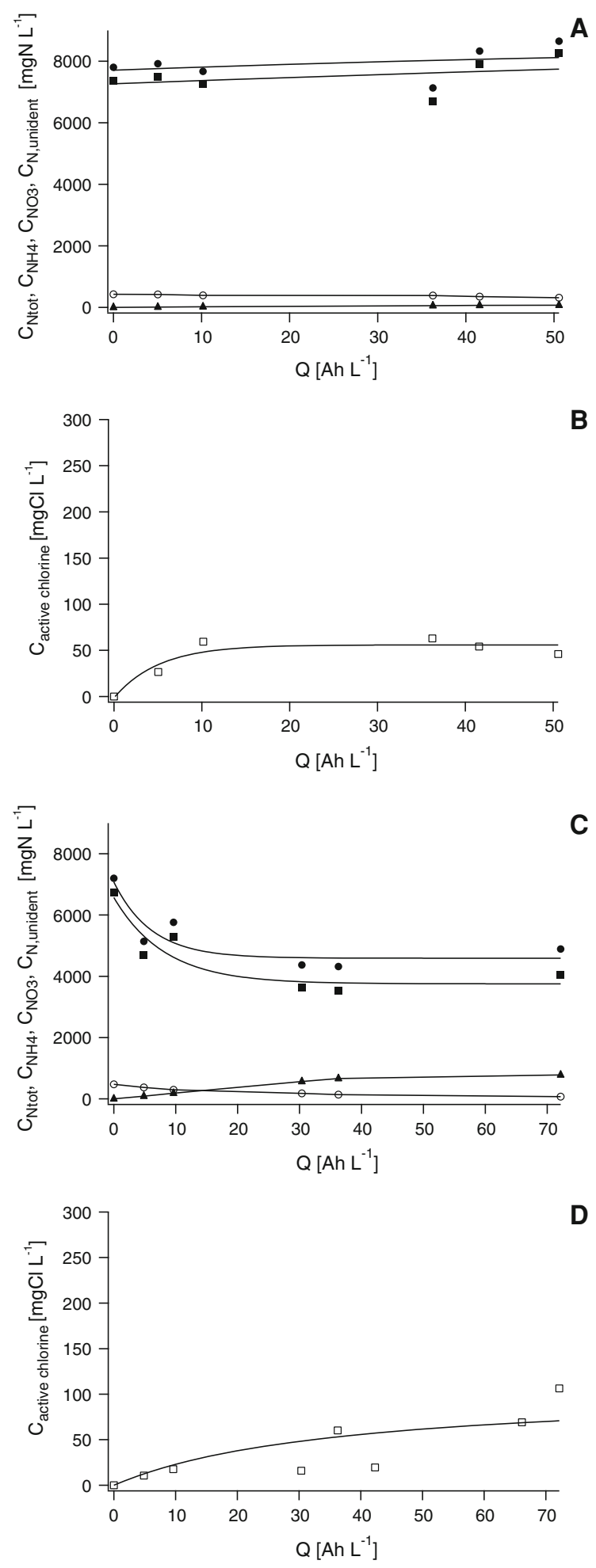

$2 \mathrm{Cl}^{-} \rightarrow \mathrm{Cl}_{2}+2 \mathrm{e}^{-}$

$\mathrm{Cl}_{2}+\mathrm{H}_{2} \mathrm{O} \rightarrow \mathrm{HOCl}+\mathrm{H}^{+}+\mathrm{Cl}^{-}$

$\mathrm{HOCl} \rightleftarrows \mathrm{OCl}^{-}+\mathrm{H}^{+}$

Hypochlorous acid is known to be a more potent oxidant than hypochlorite [30] and is able to oxidise ammonia and
Fig. 2 Galvanostatic electrolysis of synthetic fresh urine in presence of $3.24 \mathrm{gC} \mathrm{L}^{-1} \mathrm{Na}_{2} \mathrm{CO}_{3}(\mathbf{A}, \mathbf{B})$ and in absence of carbonate $(\mathbf{C}, \mathbf{D})$. Conditions: $\mathrm{pH} 10.2, \mathrm{j}=15 \mathrm{~mA} \mathrm{~cm}{ }^{-2}, \mathrm{~T}=25^{\circ} \mathrm{C}$. Filled circle total nitrogen $\left(\mathrm{C}_{\mathrm{N}_{\text {tot }}}\right)$, open circle ammonium $\left(\mathrm{C}_{\mathrm{NH}_{4}}\right)$, filled triangle nitrate $\left(\mathrm{C}_{\mathrm{NO}_{3}}\right)$, filled square non-identified nitrogen $\left(\mathrm{C}_{\mathrm{N} \text {,unident }}\right.$ : at the beginning of the experiment, this must have been urea, but it was not identified by measurements during the experiment), open square active chlorine $\left(\mathrm{C}_{\text {active chlorine }}\right)$. The formulas for the fitted curves are given in the supplementary information

urea $[30,31]$. In the reaction with ammonia, chloramines may be formed according to Eqs. 4-6 [13, 30].

$$
\begin{aligned}
& \mathrm{NH}_{3}+\mathrm{HOCl} \rightarrow \mathrm{NH}_{2} \mathrm{Cl}+\mathrm{H}_{2} \mathrm{O} \\
& \mathrm{NH}_{2} \mathrm{Cl}+\mathrm{HOCl} \rightarrow \mathrm{NHCl}_{2}+\mathrm{H}_{2} \mathrm{O} \\
& \mathrm{NHCl}_{2}+\mathrm{HOCl} \rightarrow \mathrm{NCl}_{3}+\mathrm{H}_{2} \mathrm{O}
\end{aligned}
$$

\subsection{Urea degradation in fresh urine}

Urea oxidation to nitrogen may occur either through direct oxidation, according to Eq. 7, or indirect oxidation, via electro-generated active chlorine, as indicated by Eq. 8 [32, 33]. Simka and Piotrowski [22] further differentiate indirect urea electrolysis through chlorine adsorbed at the anodic surface and through active chlorine present in the bulk of the solution. In the first case, the chloride concentration is almost constant along the experiment and no active chlorine is formed in the bulk, whereas in the latter case, active chlorine is clearly formed and participates in the oxidation of urea in the bulk of the solution.

The mechanism of urea oxidation and its products depend strongly on the process parameters, and especially on the initial concentration of chloride, the $\mathrm{pH}$ value of the solution, the applied current density, and the applied anodic potential [31, 33]. For instance, on $\mathrm{RuO}_{2}$ anodes, a more efficient indirect oxidation was observed at higher $\mathrm{pH}$ values and high $\mathrm{NaCl}$ concentrations [33].

The main products of direct urea electrooxidation depend on the $\mathrm{pH}$ : for instance, in neutral conditions, $\mathrm{CO}_{2}$ and $\mathrm{N}_{2}$ are formed, but by-products such as nitrogen dioxide $\left(\mathrm{NO}_{2}\right)$, nitrous oxide $\left(\mathrm{N}_{2} \mathrm{O}\right)$, and $\mathrm{NO}_{3}{ }^{-}$were also observed [34]. Concerning indirect urea electrolysis, it is known that ammonia and nitrate are the main products, and that ammonia can be further oxidised to $\mathrm{N}_{2}$ and $\mathrm{NO}_{3}{ }^{-}$by active chlorine [35]. Possible reaction mechanisms for nitrate production from urea in absence and in presence of active chlorine are given in Eqs. 9 and 10. These two equations are solely based on stoichiometry, since the mechanism of the indirect electrochemical oxidation of urea to nitrate has not been clarified yet.

$$
\begin{aligned}
&\left(\mathrm{NH}_{2}\right)_{2} \mathrm{CO}+\mathrm{H}_{2} \mathrm{O} \rightarrow \mathrm{CO}_{2}+\mathrm{N}_{2}+6 \mathrm{H}^{+}+6 \mathrm{e}^{-} \\
&\left(\mathrm{NH}_{2}\right)_{2} \mathrm{CO}+3 \mathrm{HOCl} \rightarrow \mathrm{CO}_{2}+\mathrm{N}_{2}+3 \mathrm{Cl}^{-}+2 \mathrm{H}_{2} \mathrm{O} \\
&+3 \mathrm{H}^{+}
\end{aligned}
$$




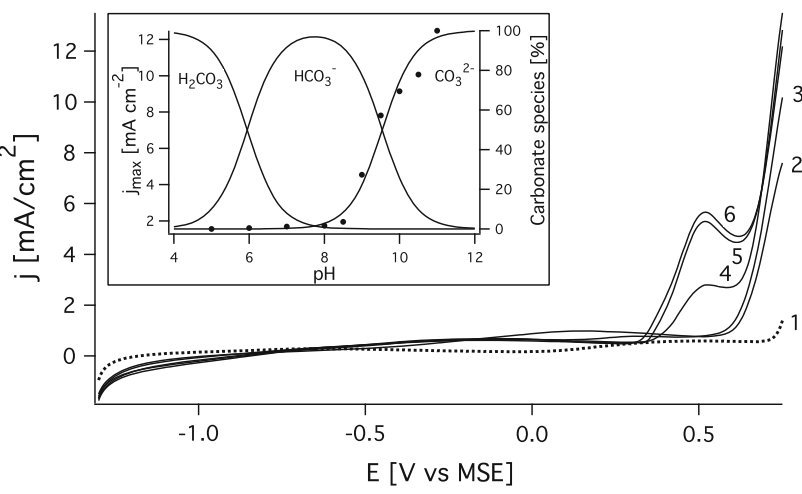

Fig. 3 Polarization curves for $1.20 \mathrm{gC} \cdot \mathrm{L}^{-1}$ of $\mathrm{Na}_{2} \mathrm{CO}_{3} / \mathrm{NaHCO}_{3}{ }^{-}$in $1 \mathrm{~mol} \cdot \mathrm{L}^{-1} \mathrm{NaClO}_{4}$. Scan rate $=50 \mathrm{mV} \mathrm{s}{ }^{-1}, \mathrm{~T}=25^{\circ} \mathrm{C}$, on $\mathrm{IrO}_{2}$ anode. Curve 1: supporting electrolyte (blank) at $\mathrm{pH} 9$, curves 2-6: $\mathrm{pH} 6,8,9,10$ and 11 . In the inset the peak current density (dots), and the calculated carbonate species concentrations (lines) are shown as function of the $\mathrm{pH}$ value

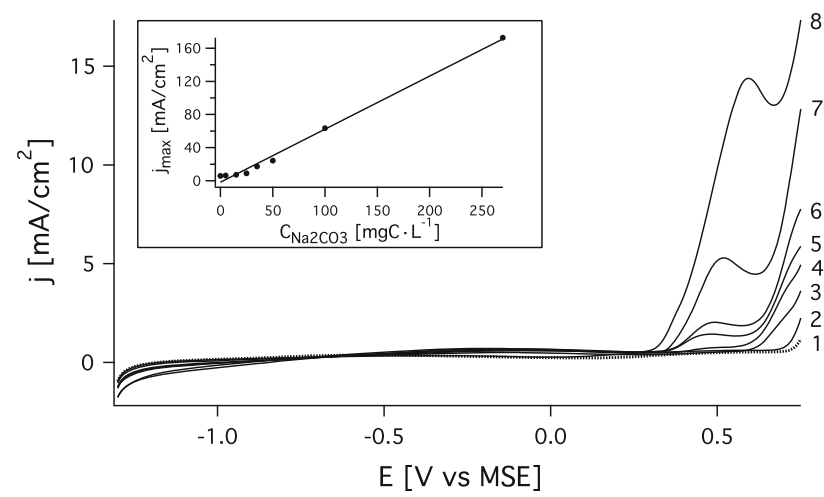

Fig. 4 Polarization curves for various concentrations of $\mathrm{Na}_{2} \mathrm{CO}_{3}$ in 1 mol L ${ }^{-1} \mathrm{NaClO}_{4}$, at $\mathrm{pH} 10$, scan rate $=50 \mathrm{mV} \mathrm{s}^{-1}, \mathrm{~T}=25^{\circ} \mathrm{C}$, on $\mathrm{IrO}_{2}$ anode. Curve 1: supporting electrolyte (blank), curves 2-8: 0.06, 0.18, $0.30,0.42,0.60,1.20$ and $3.24 \mathrm{gC} \mathrm{L}^{-1} \mathrm{Na}_{2} \mathrm{CO}_{3}$. The inset shows the peak current density as a function of the total carbonate concentration

$$
\begin{aligned}
\left(\mathrm{NH}_{2}\right)_{2} \mathrm{CO}+7 \mathrm{H}_{2} \mathrm{O} \rightarrow & 2 \mathrm{NO}_{3}^{-}+\mathrm{CO}_{2}+18 \mathrm{H}^{+}+16 \mathrm{e}^{-} \\
\left(\mathrm{NH}_{2}\right)_{2} \mathrm{CO}+8 \mathrm{HOCl} \rightarrow & 2 \mathrm{NO}_{3}^{-}+\mathrm{H}_{2} \mathrm{O}+\mathrm{CO}_{2}+10 \mathrm{H}^{+} \\
& +8 \mathrm{Cl}^{-}
\end{aligned}
$$

The nearly parallel decrease of total nitrogen and urea in Fig. 1A shows that urea was mainly oxidised to gaseous compounds such as molecular nitrogen $\mathrm{N}_{2}$ and possibly to $\mathrm{N}_{2} \mathrm{O}, \mathrm{NO}_{2}$, and nitric oxide (NO), while only a small fraction was oxidised to aqueous species, especially nitrate. The mechanism of urea oxidation may involve ammonia as intermediate, but in this case the reaction of ammonia with active chlorine was fast, as we did not observe any increase in ammonia concentration in the solution. In the present experiment, indirect oxidation by bulk active chlorine is probably the main pathway, since the concentration of
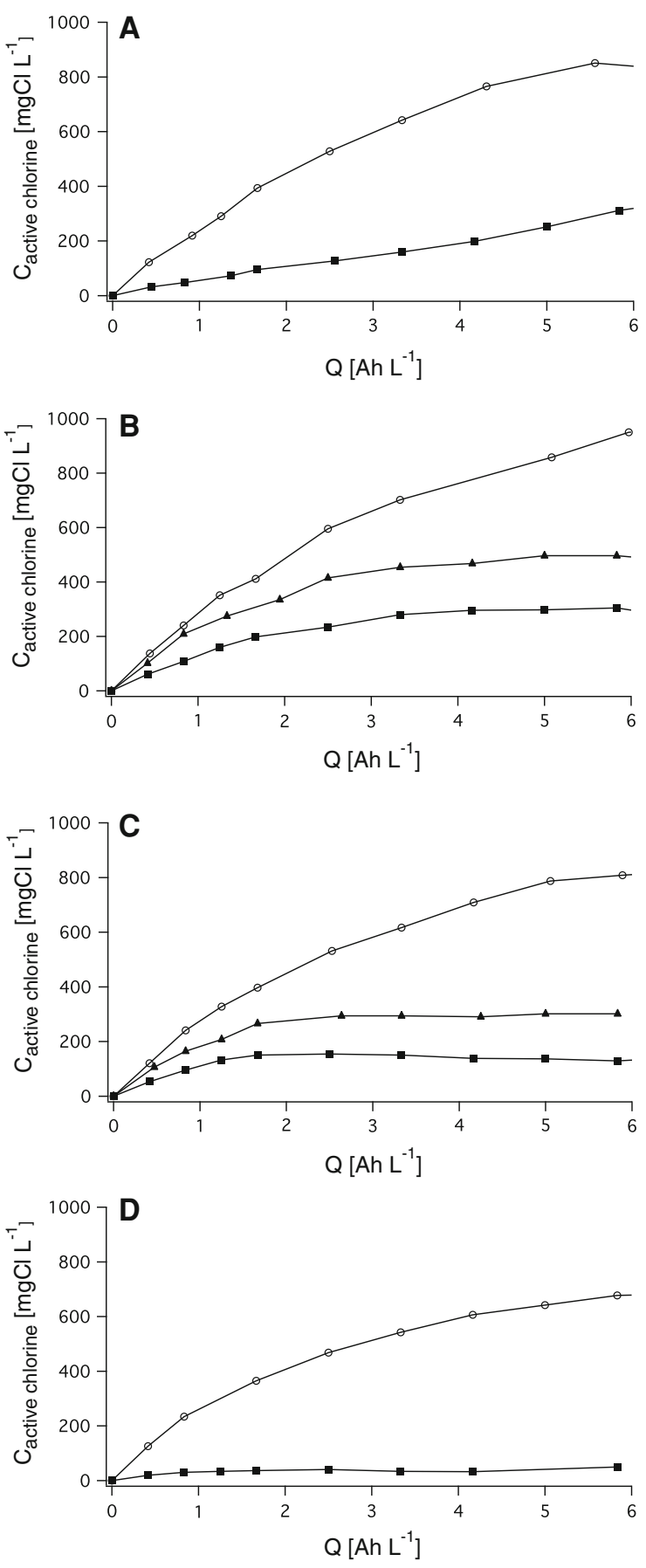

Fig. 5 Effect of carbonate on the rate of active chlorine formation during galvanostatic electrolysis in a $0.12 \mathrm{~mol} \mathrm{~L}^{-1} \mathrm{NaCl}$ solution, at pH 6 (A), 8 (B), 9 (C) and $10(\mathbf{D})$, on $\mathrm{IrO}_{2}$ anode, at $15 \mathrm{~mA} \mathrm{~cm}^{-2}$, $\mathrm{T}=25^{\circ} \mathrm{C}$. Open circle $0 \mathrm{gC} \quad \mathrm{L}^{-1} \quad \mathrm{Na}_{2} \mathrm{CO}_{3}$, filled triangle $1.68 \mathrm{gC} \mathrm{L}^{-1} \mathrm{Na}_{2} \mathrm{CO}_{3}$, filled square $3.24 \mathrm{gC} \mathrm{L}^{-1} \mathrm{Na}_{2} \mathrm{CO}_{3}$

active chlorine remained very low during the whole process, and rose when the urea concentration became low, as shown by Fig. 1B. However, we cannot exclude some direct urea oxidation, since we have not measured the anodic potential during the present experiment, and since the low level of active chlorine may also be the result of the 
Table 2 Initial $\left(\eta^{\text {initial }}\right)$ and overall $\left(\eta^{\text {overall }}\right)$ current efficiencies for $\mathrm{NO}_{3}{ }^{-}, \mathrm{N}_{2}$ and $\mathrm{Cl}_{2}$ production and selectivity towards nitrate $\left(\mathrm{K}_{\mathrm{NO}_{3}^{-}}^{\mathrm{R}}\right)$ during electrolysis of synthetic fresh urine and synthetic stored urine. $R$ denotes the sum of ammonia, ammonium and urea

\begin{tabular}{|c|c|c|}
\hline & $\begin{array}{l}\text { Fresh } \\
\text { urine, } \mathrm{pH} 6\end{array}$ & $\begin{array}{l}\text { Stored } \\
\text { urine, } \mathrm{pH} 9\end{array}$ \\
\hline Charge passed & $86 \mathrm{Ah} \mathrm{L}^{-1}$ & $86 \mathrm{Ah} \mathrm{L}^{-1}$ \\
\hline $\begin{array}{l}\text { (\% of theoretical amount for complete } \\
\text { elimination of urea or ammonia) }\end{array}$ & $(190 \%)$ & $(250 \%)$ \\
\hline$\eta_{\mathrm{Urea} \rightarrow \mathrm{NO}_{3}^{-}}^{\text {initial }}$ & $23.7 \%$ & - \\
\hline$\eta_{\mathrm{Urea} \rightarrow \mathrm{N}_{2}}^{\text {initial }}$ & $70.3 \%$ & - \\
\hline$\eta_{\mathrm{NH}_{3} \rightarrow \mathrm{NO}_{3}^{-}}^{\text {initial }}$ & - & $25.2 \%$ \\
\hline$\eta_{\mathrm{NH}_{3} \rightarrow \mathrm{N}_{2}}^{\text {initial }}$ & - & $47.6 \%$ \\
\hline$\eta_{\mathrm{Cl}^{-} \rightarrow \mathrm{Cl}_{2}}^{\text {initial }}$ & $0.4 \%$ & $0.2 \%$ \\
\hline$\eta_{\mathrm{R}, \text { total }}^{\text {initial }}=\eta_{\mathrm{R} \rightarrow \mathrm{NO}_{3}^{-}}^{\text {initial }}+\eta_{\mathrm{R} \rightarrow \mathrm{N}_{2}}^{\text {initial }}+\eta_{\mathrm{Cl}^{-} \rightarrow \mathrm{Cl}_{2}}^{\text {initial }}$ & $94.4 \%$ & $73.0 \%$ \\
\hline$\eta_{\mathrm{Urea} \rightarrow \mathrm{NO}_{3}^{-}}^{\text {overall }}$ & $31.9 \%$ & - \\
\hline$\eta_{\mathrm{Urea} \rightarrow \mathrm{N}_{2}}^{\text {overall }}$ & $37.9 \%$ & - \\
\hline$\eta_{\mathrm{NH}_{3} \rightarrow \mathrm{NO}_{3}^{-}}^{\text {overall }}$ & - & $8.6 \%$ \\
\hline$\eta_{\mathrm{NH}_{3} \rightarrow \mathrm{N}_{2}}^{\text {overall }}$ & - & $3.1 \%$ \\
\hline$\eta_{\mathrm{Cl}^{-} \rightarrow \mathrm{Cl}_{2}}^{\text {overall }}$ & $4.4 \%$ & $1.6 \%$ \\
\hline$\eta_{\mathrm{R}, \text { total }}^{\text {overall }}=\eta_{\mathrm{R} \rightarrow \mathrm{NO}_{3}^{-}}^{\text {overall }}+\eta_{\mathrm{R} \rightarrow \mathrm{N}_{2}}^{\text {overall }}+\eta_{\mathrm{Cl}^{-} \rightarrow \mathrm{Cl}_{2}}^{\text {overall }}$ & $74.2 \%$ & $13.3 \%$ \\
\hline $\mathrm{K}_{\mathrm{NO}_{3}^{-}}^{\mathrm{R}}=\frac{\eta_{\mathrm{R} \rightarrow \mathrm{NO}}^{\text {overall }}}{\eta_{\mathrm{R}, \mathrm{totala}}^{- \text {voll }}}$ & $24 \%$ & $31.8 \%$ \\
\hline Urea conversion ratio & $93 \%$ & - \\
\hline Ammonia conversion ratio & $100 \%$ & $16.9 \%$ \\
\hline Total nitrogen removal & $72.4 \%$ & $10.3 \%$ \\
\hline
\end{tabular}

inhibition or the consumption of active chlorine by other side processes. The oxidation of urea mediated by adsorbed chlorine, as defined by Simka and Piotrowski [22], did probably not occur since we clearly observed the formation of active chlorine in the bulk.

Current efficiencies for urea oxidation to molecular nitrogen and nitrate, and chlorine evolution were calculated based on the data of Fig. 1 (more details on the calculation are given in the supplementary information). Both the initial current efficiencies (initial slope of the concentration curve vs $Q$, when $Q \rightarrow 0$, see supplementary information for calculation) and the overall current efficiencies are given in Table 2; in the same table, the selectivity towards nitrate formation is also presented. For fresh urine electrolysis, the total current efficiency (sum of the identified main reactions) decreased with time, which means that some unknown side reactions became important or some losses occurred. A possible loss is the volatilization of gaseous chlorine. Furthermore, thermally prepared $\mathrm{IrO}_{2}$ electrodes are known to show an electrocatalytic activity for oxygen evolution [36], and, as the cell potential slightly increased during the electrolysis, oxygen evolution (Eq. 11) may have occurred. Then, some chloramines were probably formed according to Eqs. 4-6 [30]. Finally, both the chemical and electrochemical formation of chlorate (Eqs. 12, 13) have been reported in similar conditions [31].

$$
\begin{aligned}
& 2 \mathrm{H}_{2} \mathrm{O} \rightarrow \mathrm{O}_{2}+4 \mathrm{H}^{+}+4 \mathrm{e}^{-} \\
& 6 \mathrm{ClO}^{-}+3 \mathrm{H}_{2} \mathrm{O} \rightarrow 2 \mathrm{ClO}_{3}^{-}+4 \mathrm{Cl}^{-}+6 \mathrm{H}^{+}+\frac{3}{2} \mathrm{O}_{2}+6 \mathrm{e}^{-}
\end{aligned}
$$

$$
2 \mathrm{HClO}+\mathrm{ClO}^{-} \rightarrow \mathrm{ClO}_{3}^{-}+2 \mathrm{Cl}^{-}+2 \mathrm{H}^{+}
$$

According to our data, most of the urea and ammonia were removed from fresh urine during the $48 \mathrm{~h}$ electrolysis experiment. Only $27.6 \%$ of the nitrogen remained in the solution, from which $24 \%$ in the form of nitrate. The overall current efficiency of the process was $74.2 \%$, which is a considerably good value.

\subsection{Ammonia degradation in stored urine}

Ammonia can be efficiently degraded by direct oxidation on $\mathrm{IrO}_{2}$ electrode in alkaline $\mathrm{pH}$ solutions, but not in neutral and acidic conditions. Indeed, only the species $\mathrm{NH}_{3}$ is oxidised, whereas ammonium $\left(\mathrm{NH}_{4}{ }^{+}\right)$remains electrochemically inert (Eq. 14) [18, 21]. Under non-alkaline conditions, ammonium can be oxidised indirectly by electro-generated active chlorine [18]. This process is supported by the speciation of active chlorine: at a $\mathrm{pH}$ value below 7.5, the major species is hypochlorous acid, which is a more potent oxidant than hypochlorite (Eq. 15) [30]. Indirect oxidation by active chlorine has also been proposed as major ammonia degradation mechanism for BDD and other DSA electrodes (see e.g. [13, 16, 37]).

$\mathrm{NH}_{3} \rightarrow \frac{1}{2} \mathrm{~N}_{2}+3 \mathrm{H}^{+}+3 \mathrm{e}^{-}$

$2 \mathrm{NH}_{4}^{+}+3 \mathrm{HOCl} \rightarrow \mathrm{N}_{2}+3 \mathrm{Cl}^{-}+5 \mathrm{H}^{+}+3 \mathrm{H}_{2} \mathrm{O}$

During electrolysis of stored urine, total nitrogen and ammonia concentrations decreased only slightly at the beginning of the experiment and then remained constant within experimental errors (Fig. 1C). Apparently, ammonia was neither oxidised directly nor by electro-generated active chlorine. Hardly any nitrogen left the solution, suggesting that no volatile nitrogen compounds were produced. Only nitrate was formed in appreciable amounts, probably following Eqs. 16 [37] or 17. Equation 17 is based on stoichiometry, since the mechanism of nitrate formation from ammonia through active chlorine has not been completely clarified yet.

$\mathrm{NH}_{3}+3 \mathrm{H}_{2} \mathrm{O} \rightarrow \mathrm{NO}_{3}^{-}+9 \mathrm{H}^{+}+8 \mathrm{e}^{-}$
$\mathrm{NH}_{3}+4 \mathrm{HOCl} \rightarrow \mathrm{NO}_{3}^{-}+4 \mathrm{Cl}^{-}+5 \mathrm{H}^{+}+\mathrm{H}_{2} \mathrm{O}$

Initial and overall current efficiencies, for ammonia oxidation to molecular nitrogen and nitrate and for chlorine 
formation are given in Table 2. The initial current efficiencies were high, but they strongly decreased until the end of the treatment. Overall, only $10.3 \%$ of ammonia was removed, and $31.8 \%$ of the removed ammonia was oxidised to nitrate. Figure 1D shows that the amount of active chlorine in the bulk of the solution remained very constant and low throughout the experiment. This suggests either an inhibition of active chlorine formation or the consumption of active chlorine by another competing reaction. Chemical and electrochemical formation of chlorate (Eqs. 9, 10) have been reported to occur in dilute active chlorine solutions and might have consumed active chlorine $[31,38]$.

The overall total current efficiency in the experiment with stored urine was only $13.3 \%$. This value is much lower than in the experiment on urea electrolysis. Side reactions at the surface of the electrode such as the oxidation of water (Eq. 11), the electrochemical formation of chlorate (Eq. 12) and the oxidation of carbonate (Eq. 18) may explain this difference.

\subsection{Carbonate oxidation}

During cyclic voltammetry of carbonate solutions at different $\mathrm{pH}$ values the peak maximum current density correlated well with the $\mathrm{CO}_{3}{ }^{2-}$ species concentration (inset of Fig. 3). Zhang and Oloman, and Van der Wiel and Janssen $[39,40]$ suggested a mechanism for carbonate oxidation on platinum electrodes: carbonate is oxidised to percarbonate (Eq. 18), which is further hydrolysed to bicarbonate and hydrogen peroxide (Eq. 19). Hydrogen peroxide may finally be oxidised at the surface of the anode to oxygen (Eq. 20). During the overall reaction $2 \mathrm{~mol}$ of protons are released per mole of carbonate oxidised. This should lead to a $\mathrm{pH}$ decrease, if the solutions were not as strongly buffered as in our experiments. The half time of percarbonate was reported to be $1-2 \mathrm{~min}$ at $\mathrm{pH} 10$ and $15{ }^{\circ} \mathrm{C}$ [40]. The oxidation of carbonate to percarbonate was also reported on BDD electrodes at alkaline conditions [41].

$$
\begin{aligned}
& 2 \mathrm{CO}_{3}^{2-} \rightarrow \mathrm{C}_{2} \mathrm{O}_{6}^{2-}+2 \mathrm{e}^{-} \\
& \mathrm{C}_{2} \mathrm{O}_{6}^{2-}+2 \mathrm{H}_{2} \mathrm{O} \rightarrow 2 \mathrm{CO}_{3}^{2-}+\mathrm{H}_{2} \mathrm{O}_{2}+2 \mathrm{H}^{+} \\
& \mathrm{H}_{2} \mathrm{O}_{2} \rightarrow \mathrm{O}_{2}+2 \mathrm{H}^{+}+2 \mathrm{e}^{-}
\end{aligned}
$$

The electrochemical oxidation of carbonate not only lowered the current efficiency for ammonia oxidation, it is also the likely reason for the inhibition of ammonia and chlorine oxidation. This can be shown by comparing oxidation potentials: the observed oxidation potential of $3.24 \mathrm{gC} \mathrm{L}^{-1}$ carbonate at $\mathrm{pH} 10$ on our $\mathrm{IrO}_{2}$ anode (onset potential $=0.35 \mathrm{~V}$ vs MSE, Figs. 3, 4) is lower than the potential for chloride oxidation (onset potential $=0.7 \mathrm{~V} \mathrm{vs}$ MSE for $1 \mathrm{~mol} \mathrm{~L}^{-1}$ ), and similar to the one of ammonia oxidation (onset potential $=0.45 \mathrm{~V}$ vs MSE, for $0.1 \mathrm{~mol} \mathrm{~L}^{-1}$ ) on $\mathrm{IrO}_{2}$ electrodes [42]. Due to its lower oxidation potential, carbonate oxidation (Eq. 18) at the surface of the electrode competes and may overcome the reaction of chlorine evolution (Eq. 1), as well as the reaction of direct ammonia oxidation (Eqs. 14, 16).

\subsection{Hypochlorite consumption}

$\mathrm{CO}_{3}{ }^{2-}$ oxidation alone cannot explain the low active chlorine production at lower $\mathrm{pH}$ values (Fig. 5A, B). In neutral and slightly acidic conditions, carbonate is predominantly present in the form of bicarbonate $\mathrm{HCO}_{3}{ }^{-}$and carbonic acid $\mathrm{H}_{2} \mathrm{CO}_{3}$, which are not oxidised at the same low potentials as $\mathrm{CO}_{3}{ }^{2-}$ (Fig. 3). One process that reduces the availability of active chlorine may be the formation of chlorate. Jung et al. [43] suggest that active chlorine electrochemical oxidation to chlorate is more efficient at $\mathrm{pH}$ values above 7.2. Based on their observations, they proposed that hypochlorite ion is the active chlorine species that is converted electrochemically to chlorate, whereas hypochlorous acid would rather be converted chemically to chlorate, but in a less efficient reaction. The electrochemical conversion of active chlorine to chlorate under alkaline and neutral conditions has also been proposed by several studies [38, 44]. In our experiments, the strong buffering effect of carbonate could have enhanced the electrochemical (in alkaline solutions) and chemical (in slightly acidic solutions) conversion of active chlorine to chlorate (Eqs. 12, 13) in the diffusion layer close to the electrode. However, a final conclusion is not possible, because we did not measure the chlorate concentrations.

\subsection{Effect of carbonate on nitrogen removal}

Based on these considerations, we propose that the inefficient ammonia and urea degradation at high carbonate $\left(\mathrm{CO}_{3}{ }^{2-}\right)$ concentrations is mainly a consequence of the anodic oxidation of carbonate into percarbonate. An additional process that reduces the efficiency of ammonia and urea oxidation could be the removal of active chlorine through chlorate formation in the diffusion layer, enhanced by the buffering effect of carbonate. However, further experiments are needed to prove this hypothesis.

The results of Fig. 2C may be explained as follows: at the beginning of the electrolysis, no carbonate is present, and urea is degraded. However, urea degradation leads to the formation of $\mathrm{CO}_{2}$ (Eqs. 7-10), which exists mainly as $\mathrm{CO}_{3}{ }^{2-}$ under alkaline conditions, and thus inhibits further urea oxidation. This is an auto-inhibition mechanism of urea oxidation in alkaline conditions on $\mathrm{IrO}_{2}$ electrode. However, under slightly acidic conditions (Figs. 1A, 5A), carbonate inhibits the formation of active chlorine only 
slightly, which may affect the efficiency of indirect urea oxidation, but not direct urea oxidation.

\section{Conclusions}

- In fresh urine, urea and ammonia can be efficiently oxidised on $\mathrm{IrO}_{2}$ electrodes, but in stored urine ammonia cannot be oxidised with the same electrode. If electrolysis is used for nitrogen removal from urine, the reactor should be located very close to the toilet in order to collect the urine, before urea has been hydrolysed in the pipes.

- High carbonate $\left(\mathrm{CO}_{3}{ }^{2-}\right)$ concentrations are responsible for the insufficient ammonia electrolysis in stored urine. Carbonate is oxidised at a relatively low potential (about $0.35 \mathrm{~V}$ vs MSE on $\mathrm{IrO}_{2}$ ) and thereby outcompetes direct ammonia oxidation and formation of active chlorine. A second influence on the current efficiency could be the enhanced conversion of active chlorine to chlorate due to the high $\mathrm{pH}$ values in the carbonate buffer.

- The presence of carbonate might not only be a problem for the electrolytic removal of ammonia and urea from urine on $\mathrm{IrO}_{2}$ anode but also for other solutions and processes that involve chlorine mediated oxidation at elevated $\mathrm{pH}$ values.

- Further research on ammonia removal from stored urine should focus on finding electrodes that have higher oxidation potentials for carbonate than for chloride and ammonia.

Acknowledgments Funding for this project was provided by the Bill and Melinda Gates Foundation.

\section{References}

1. Larsen TA, Maurer M, Udert KM, Lienert J (2007) Water Sci Technol 56:229

2. Larsen TA, Alder AC, Eggen RIL, Maurer M, Lienert J (2009) Environ Sci Technol 16:6121

3. Maurer M, Pronk W, Larsen TA (2006) Water Res 40:3151

4. Udert KM, Wächter M (2012) Water Res 46:453

5. Bürgmann H, Jenni S, Vazquez F, Udert KM (2011) Appl Environ Microbiol 77:5897

6. Başakçılardan-Kabakcı S, İpekoğlu AN, Talınlı İ (2007) Environ Eng Sci 24:615

7. Anglada A, Urtiaga A, Ortiz I (2009) J Chem Technol Biotechnol 84:1747

8. Panizza M (2010) In: Comninellis C, Chen G (eds) Electrochemistry for the environment. Springer, New York, p 35

9. Rosca V, Duca M, DeGroot MT, Koper MTM (2009) Chem Rev 109:2209
10. Muthuvel M, Botte GG (2009) In: White RE (ed) Modern aspects of electrochemistry. Springer Science and Business Media, New York, pp 207-245

11. Boggs BK, King RL, Botte GG (2009) Chem Commun 32:4859

12. Diaz V, Ibanez R, Gomez P, Urtiaga AM, Ortiz I (2011) Water Res 45:125

13. Kapalka A, Katsaounis A, Michels NL, Leonidova A, Souentie S, Comninellis C, Udert KM (2010) Electrochem Commun 12:1203

14. Bunce NJ, Bejan D (2011) Electrochim Acta 56:8085

15. Gerischer H, Mauerer A (1970) J Electroanal Chem 25:421

16. Kapalka A, Joss L, Anglada A, Comninellis C, Udert KM (2010) Electrochem Commun 12:1714

17. Kapalka A, Cally A, Neodo S, Comninellis C, Wächter M, Udert KM (2010) Electrochem Commun 12:18

18. Kim KW, Kim YJ, Kim IT, Park GI, Lee EH (2005) Electrochim Acta 50:4356

19. Kapalka A, Fierro S, Frontistis Z, Katsaounis A, Frey O, Koudelka M, Comninellis C, Udert KM (2009) Electrochem Commun 11:1590

20. Michels NL, Kapalka A, Abd-El-Latif AA, Baltruschat H, Comninellis C (2010) Electrochem Commun 12:1199

21. Kapalka A, Fierro S, Frontistis Z, Katsaounis A, Neodo S, Frey O, de Rooij N, Udert KM, Comninellis C (2011) Electrochim Acta 56:1361

22. Simka W, Piotrowski J (2007) Przem Chem $86: 841$

23. King RL, Botte GG (2011) J Power Sources 196:9579

24. Ikematso M, Kaneda K, Iseki M, Matsuura H, Yasuda M (2006) Chem Lett 35:576

25. Udert KM, Larsen TA, Biebow M, Gujer W (2003) Water Res 37:2571

26. Udert KM, Larsen TA, Gujer W (2006) Water Sci Technol $54: 413$

27. Ouattara L, Fierro S, Frey O, Koudelka M, Comninellis C (2009) J Appl Electrochem 39:1361

28. Randtke SJ (2010) In: Black \& Veatch Corporation (ed) White's handbook of chlorination and alternative disinfectants. John Wiley and Sons, New Jersey, p 183

29. Kraft A, Stadelmann M, Blaschke M, Kreysig D, Sandt B, Schroder F, Rennau J (1999) J Appl Electrochem 29:861

30. Devkota LM, Williams DS, Matta JH, Albertson OE, Grasso D, Fox P (2000) Water Environ Res 72:610

31. Hernlem BJ (2005) Water Res 39:2245

32. Simka W, Piotrowski J, Robak A, Nawrat G (2009) J Appl Electrochem 39:1137

33. Wright JC, Michaels AS, Appleby AJ (1986) AIChE J 32:1450

34. Bezerra ACS, de Sá EL, Nart FC (1997) J Phys Chem B 101:6443

35. Di Giulio S, Jara CC, Fino D, Saracco G, Specchia V, Spinelli P (2007) Ind Eng Chem Res 46:6783

36. Trasatti S (1984) Electrochim Acta 29:1503

37. Vanlangendonck Y, Corbisier D, Van Lierde A (2005) Water Res 39:3028

38. Landolt D, Ibl N (1970) Electrochim Acta 15:1165

39. Van der Wiel PM, Janssen LJJ, Hoogland JG (1971) Electrochim Acta 16:1217

40. Zhang JJ, Oloman CW (2005) J Appl Electrochem 35:945

41. Ruiz EJ, Ortega-Borges R, Jurado JL, Chapman TW, Meas Y (2009) Electrochem Solid-State Lett 12:E1

42. Kim K-W, Kim Y-J, Kim I-T, Park G-II, Lee E-H (2006) Water Res 40:1431

43. Jung YJ, Baek KW, Oh BS, Kang JW (2010) Water Res 44:5345

44. Czarnetzki LR, Janssen LJJ (1992) J Appl Electrochem 22:315 